\title{
BULLETIN
}

\section{OF THE \\ AMERICAN \\ MATHEMATICAL SOCIETY}

\author{
A Historical and Critical Review \\ of Mathematical Science
}

EDITED BY

EARLE R. HEDRICK

DAVID R CURTISS

WILLIAM R. LONGLEY

WITH THE ASSISTANCE OF

THEOPHIL H. HILDEBRANDT

TULLIO LEVI-CIVITA

HARRY W. KUHN

HENRY L. RIETZ

DERRICK N. LEHMER

CAROLINE E. SEELY

J. H. M. WEDDERBURN

\section{Volume XXXIV}

January to December, I928

PUBLISHED BY THE SOCIETY MENASHA, WIS., AND NEW YORK

1928 
The Culleginte Wraw

GRORGE BANTA PUBLISHING COMPANT MENABEA, WIBCONSIN 


\title{
BULLETIN
}

OF THE

\section{AMERICAN}

\section{MATHEMATICAL SOCIETY}

\author{
A Historical and Critical Review \\ of Mathematical Science
}

\author{
EDITED BY
}

EARLE R. HEDRICK

DAVID R. CURTISS

WILLIAM R. LONGLEY

WTTH THE ASSISTANCE OF

THEOPHIL H. HILDEBRANDT

HARRY W. KUHN

DERRICK N. LEHMER

TULLIO LEVI-CIVITA

HENRY L. RIETZ

CAROLINE E. SEELY

J. H. M. WEDDERBURN

Volume XXXIV, Number I

JANUARY-FEBRUARY, I928

PUBLISHED BY THE SOCIETY

MENASHA, WIS., AND NEW YORK

1928

\section{Published Bimonthly}

Whole No. 352

$\$ 7.00$ a Year

Entered as second class matter at the post office at Menasha, Wis., May 13, 1926. 


\section{JOURNALS OF THIS SOCIETY}

For complete price list, see the July-August issue.

I. THE TRANSACTIONS

To members, $\$ 5.25$; to others, $\$ 7.00$.

II. THE BULLETIN

To members, free; to others, $\$ 7.00$.

III. THE AMERICAN JOURNAL OF MATHEMATICS

Published by this Society and the Johns Hopkins University.

To members, $\$ 5.25$; to others, $\$ 6.00$.

\section{THE COLLOQUIUM PUBLICATIONS}

\section{ANNOUNCEMENT OF NEW VOLUMES}

G. C. Evans, The Logarithmic Potential. Discontinuous Dirichlet and Neumann Problems. 1927. $150 \mathrm{pp}$. To members, $\$ 1.50$; to others, $\$ 2.00$.

E. T. Bell, Algebraic Arithmetic. Nearly ready. To members, $\$ 2.00$; to others, $\$ 2.50$.

L. P. Eisenhart, Non-Riemannian Geometry. In preparation.

G. D. Birkhoff, Dynamical Systems. In preparation.

These volumes are bound in cloth, and are each of about 200 pp. For earlier issues of this series, see a flyleaf of the May-June issue.

A. B. Coble, E. R. Hedrick, W. R. Longley (Chairman)

Committee on Sales of Publications

Orders may be addressed to

501 WEST 116TH STREET, NEW YORK, N.Y.

On sale also by the following official agents of this Society:

The Open Court Publishing Co., 337 E. Chicago Ave., Chicago, IIl.

Bowes \& Bowes, 1 Trinity St., Cambridge, England.

Hirschwaldsche Buchhandlung, Unter den Linden, 68, Berlin. 